تعيين تناسب اراضى مزارع نيشكر مبتنى بر شاخص كيفيت خاك با استفاده از سامانه اطلاعات جغر افيايى

عليرضا ظهيرنيا* و حميدرضا متين فر

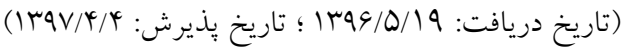

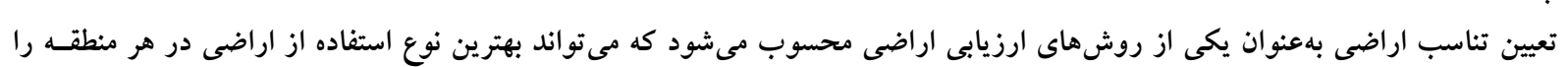

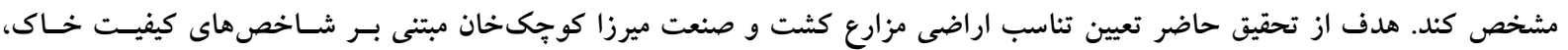

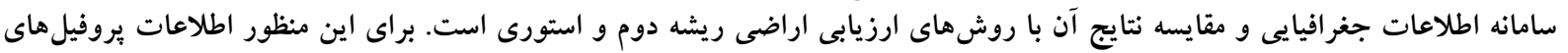

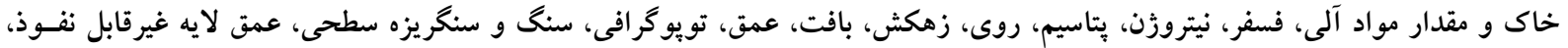

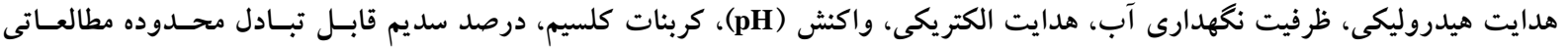

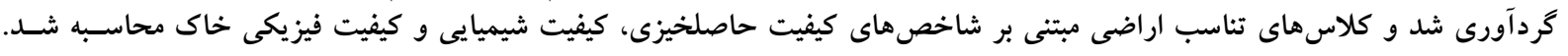

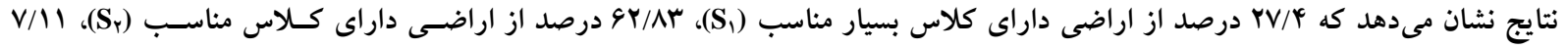

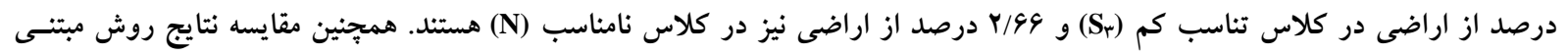

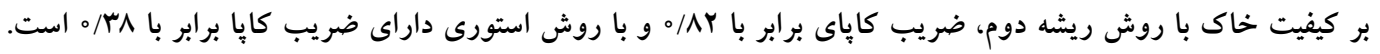

وازههاى كليدى: ارزيابى اراضى، منطقه جنوب غربى خوزستان، نقشههاى رقومى، روش استورى، روش ريشه دوم.

1. كروه مهندسى علوم خاك، دانشكده كشاورزى، دانشخاه لرستان، لرستان

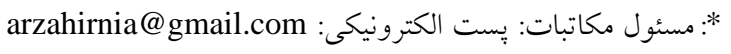




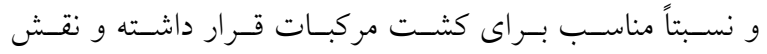

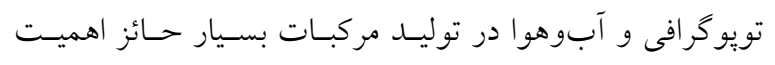

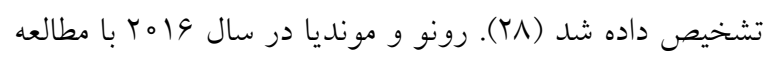

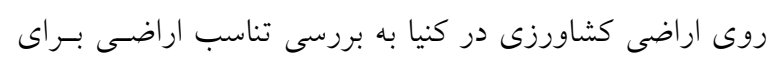

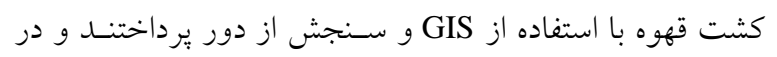

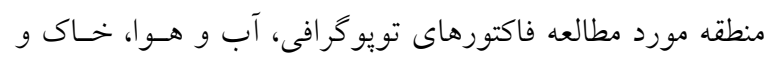

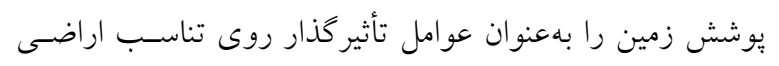

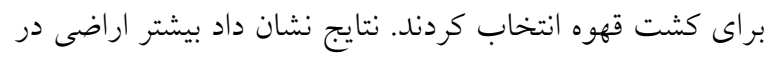

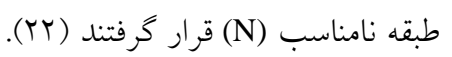

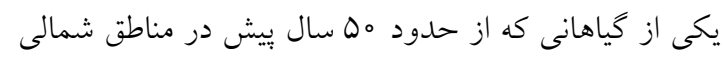

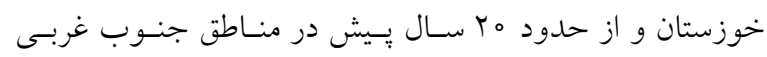

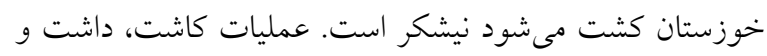

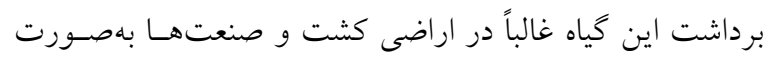

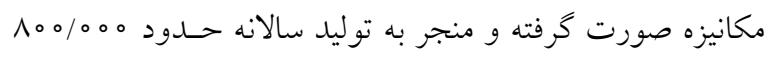

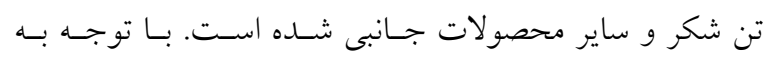

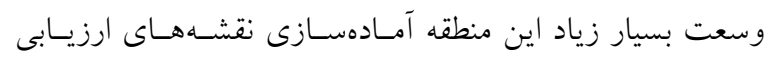

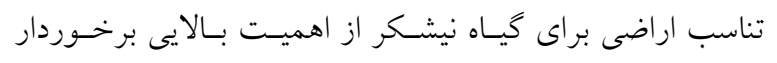

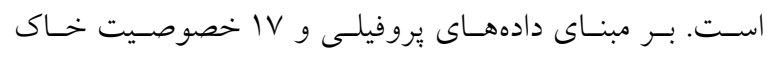

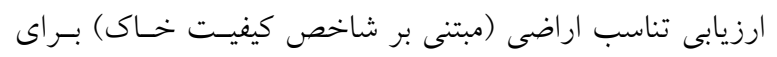
بخشى از منطقه جنوب غربى خوزستان و مقايسـه نتسايج ايسن

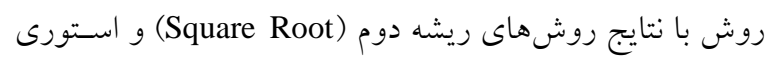
بهنوان هدف اصلى يُزوهش حاضر بود.

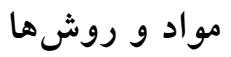
موقعيت منطقه مورد مطالعه منطقسه مـورد مطالعـه مـزارع نيشـكر شـركت و صسنعت ميـرزا

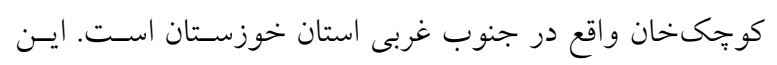

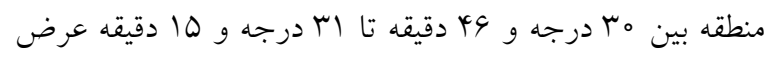

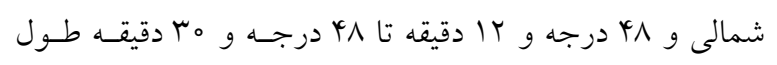

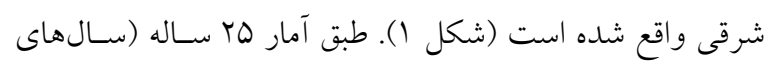
هو

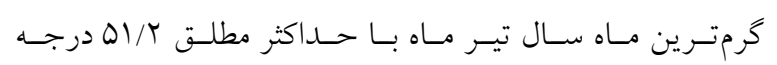

بررسى تناسب اراضى تعيين كننده بهترين نوع استفاده از اراضى

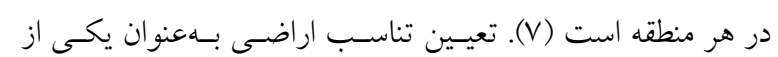
روشهاى ارزيابى اراضى محسوب مى شود كه مىتواند مهمتسرين

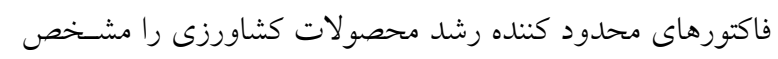

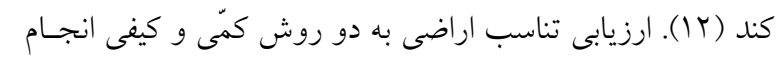

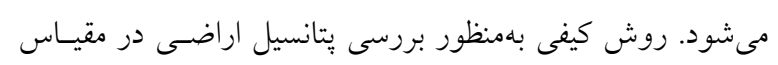

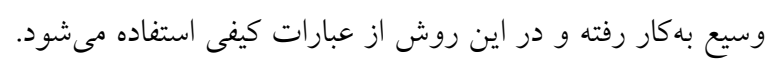

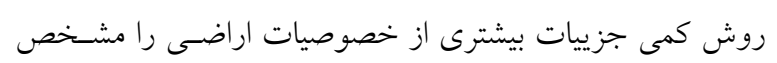

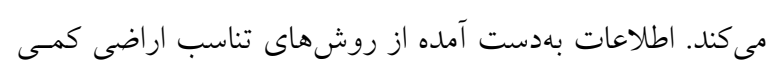

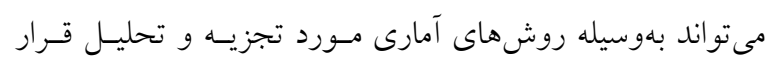

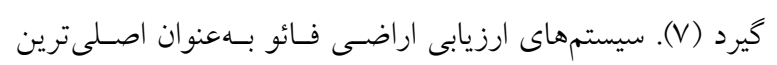

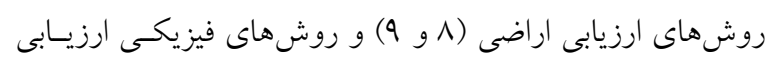

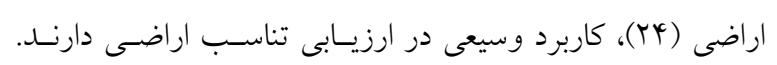

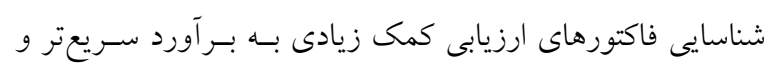

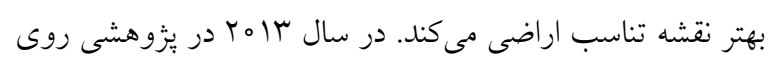

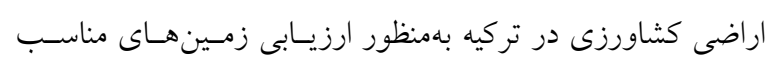

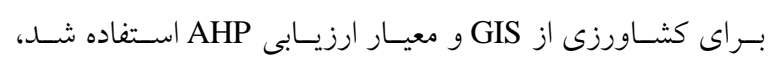

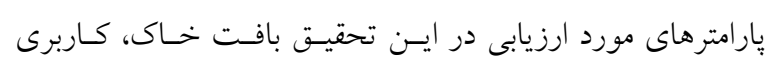

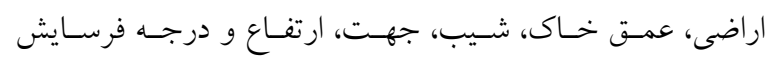

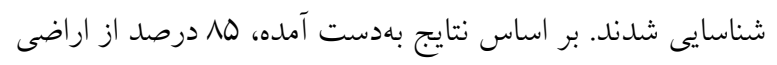
بهلت شيب زياد و خاك فرسـايش يافتسه قابليـت كشـاورزى را

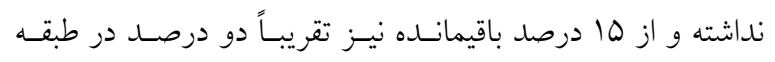

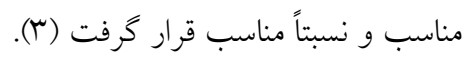

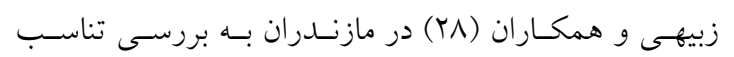

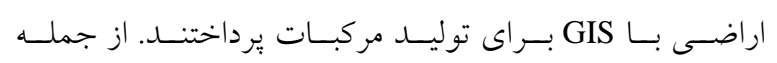

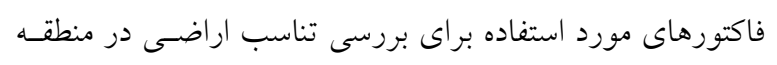

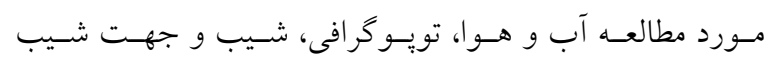

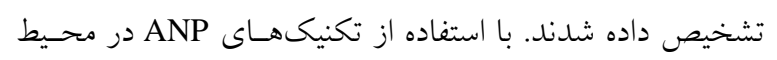

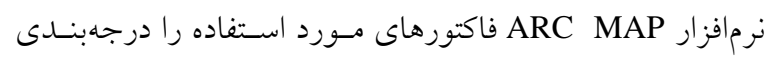

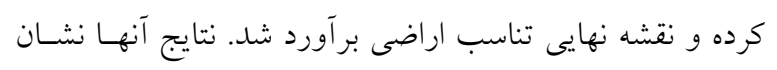

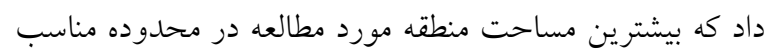




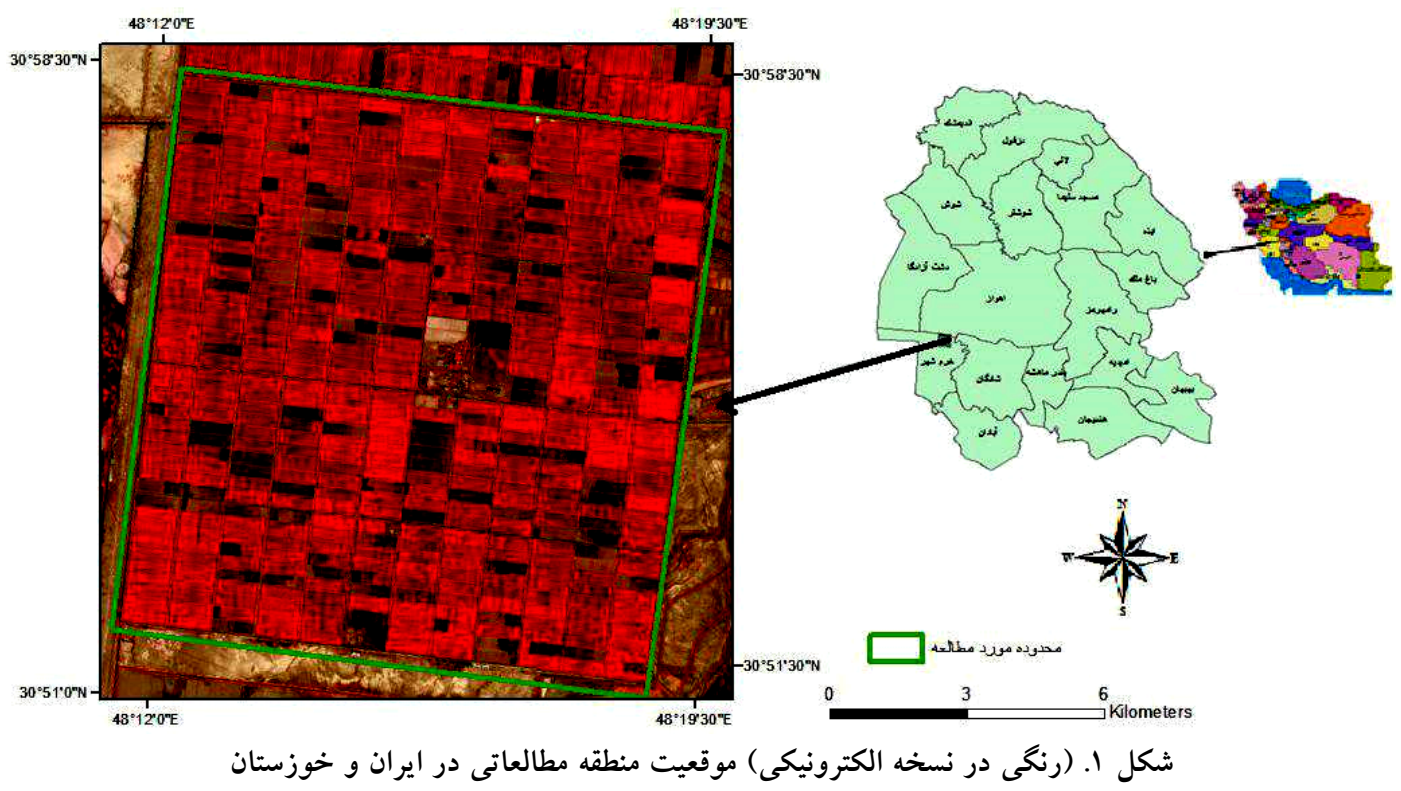

19 19 مطابق با هشتم مرداد ماه ه9 1 استفاده شد. تصحيحات هندسى و اتمسفرى روى تصـاوير انجـام شــد. تصـوير مـورد

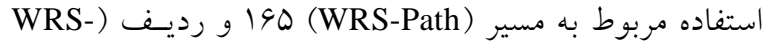
(Row اسكن و زئورفرنس شده و بهاعنوان نقشه يايسه مـورد اسـتفاده قرار كرفتند (

مطالعات آزمايشخاهى و صحرايى

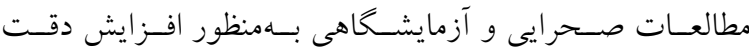
عوارض تشخيص داده شده در تصاوير ماهوارهاى و جداسـازى بهتر و كامل تر عوارض موجود در سطح زمين انجام شد. تعسداد با بروفيل در اراضى مـورد مطالعـه حفـر شــ (شـكل r) و از

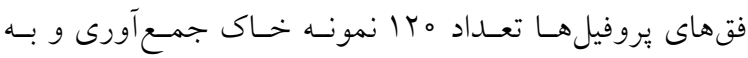
آزمايشخاه خاكشناسى منتقل شد. رنخ خاك بر اسـاس دفترجـــ رنگ مانسل در دو حالـت خشـك و مرطسوب و همجنـين وزن مخصوص ظاهرى هر افق با اسـتفاده از سـيلندرهاى اسـتاندارد

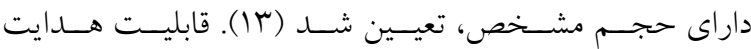

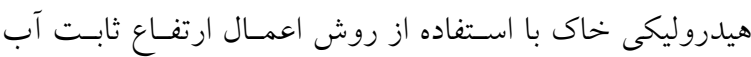
خاى اشباع تعيين شد (19).
سانتى گراد، بارندگى كمتر از مقدار تبخير ساليانه (rاب در مقابل T TYM ميلى متر) و رزيمهاى حرارتى و رطوبتى محاسبه شده بـر اساس روش نيوهال بهترتيب هايبرترميـك و اريسـيك هسـتند. سـازندهــاى منطقـهـ از نظـــر زمينشناسـى مربــوط بــه دوران سنوزوئيك و دوره كواترنر است. كشت غالب منطقه در اراضسى آبشويى شده واريتـههـاى مختلـف نيشـكر و در سـاير اراضسى محصولاتى مانند كندم، جو، كلـزا، كنجـــ و گلرنــ بهصـورت محدود هستند. گياهان بومى منطقه غالبـاً از كياهـان شوريســن مانند خانو اده اسفناج، خارشتر، شاهى و كاهوى وحشى تشـيل

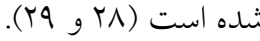

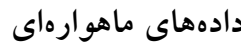
دادههاى ماهواره لندسـت هشـت بـهعلت جنـــ طيفى بـودن امـكان مـطالعه منابع مخـتلف در طول مـوجهــاى متنـوعى از مرئى تا مادون قرمز را فراهم آورده است. از ويز كىهاى ديخر اين دادهها متنوع بودن آنها است. دادههاى اين ماهواره شـامل 11 باند هستند كه هر 19 روز يكبار توسط سـنجنده تصـوير OLI- بردارى مىشوند. در بزوهش حاضر از تصوير سـنجنده متعلق به ماهواره لندست هشـت و تساريخ بو جـو TIRS 
نشر يه علوم آب و خاك (علوم و فنون كشاورزى و منابع طبيعى) / سال بيست و سه / شماره دوم / تابستان لهه|

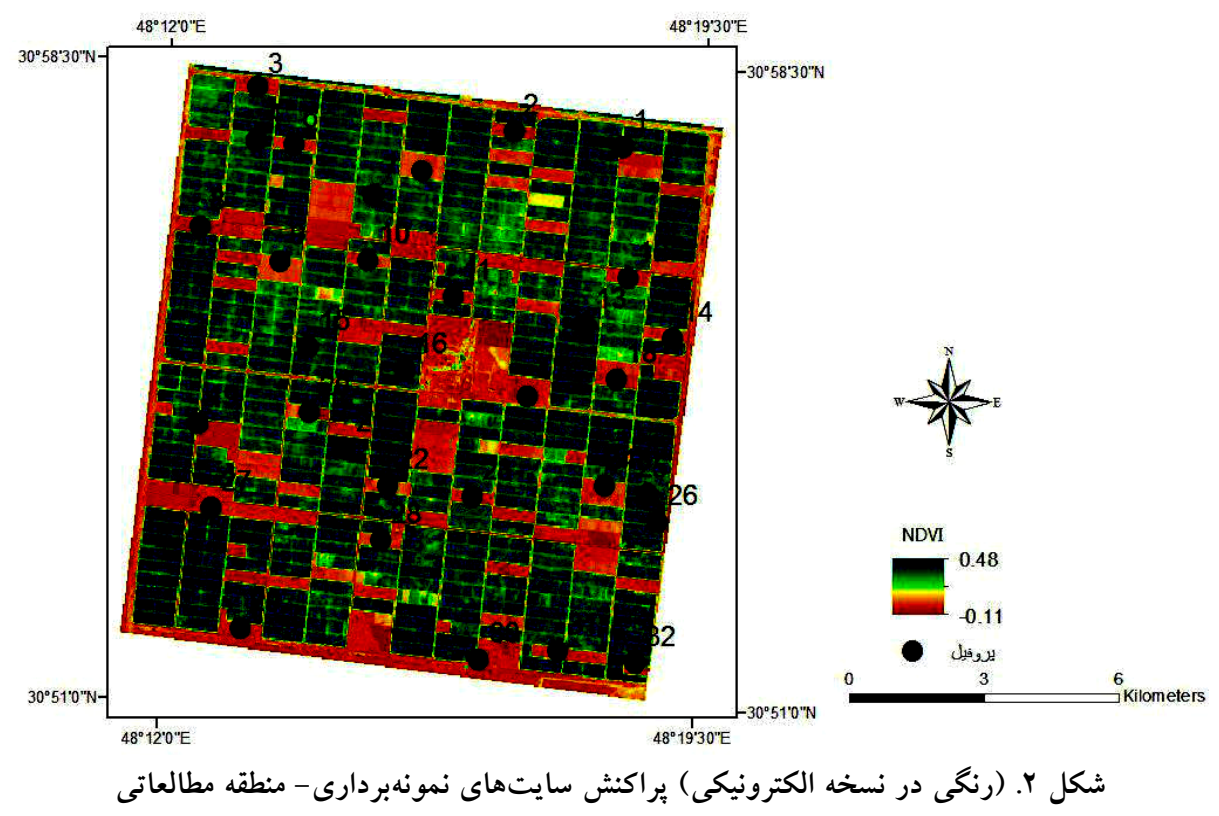

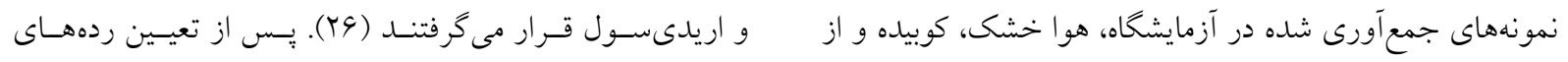

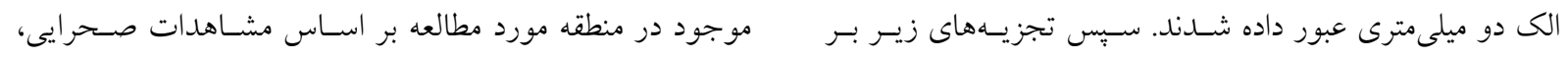

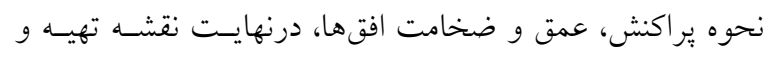

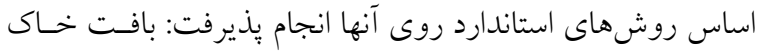

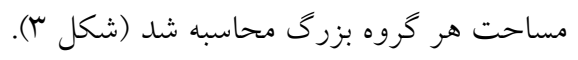

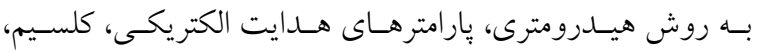

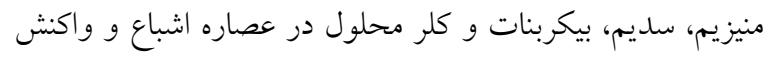

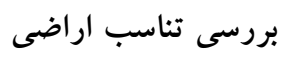

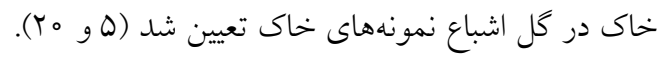

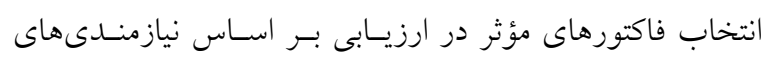

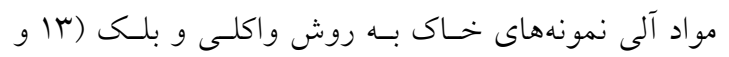

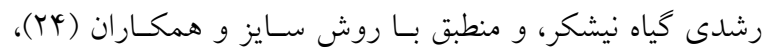

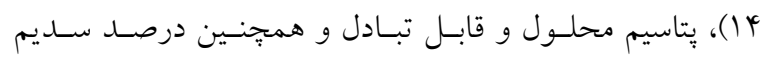

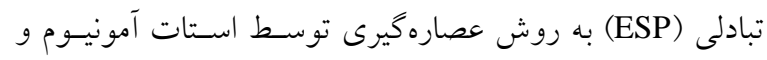

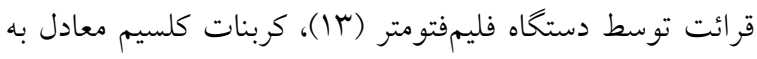

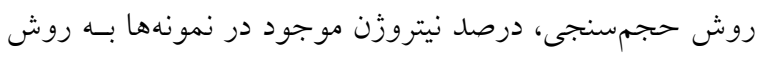

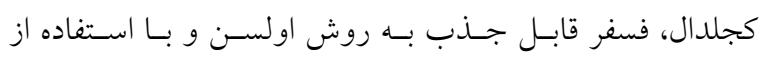

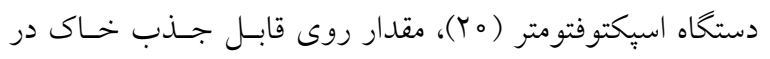

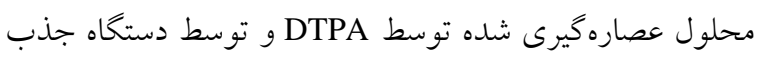

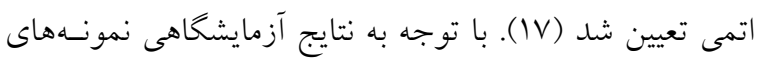
بهنظور بررسى تناسب اراضس (Land Suitability) از سـه شاخص استفاده شد كه عبارتند از: شاخص كيفيت حاصلخيزى بن راصى خـاك (Fertility Quality Index)، شـاخص كيفيـت شـيمياييى

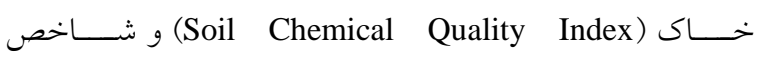

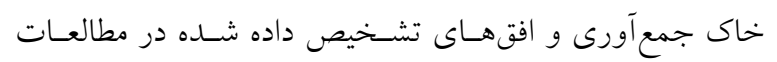

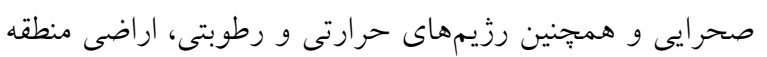

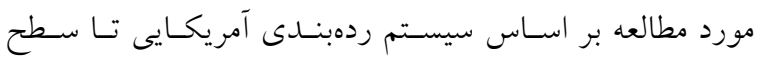

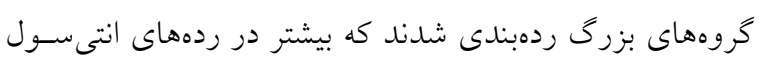




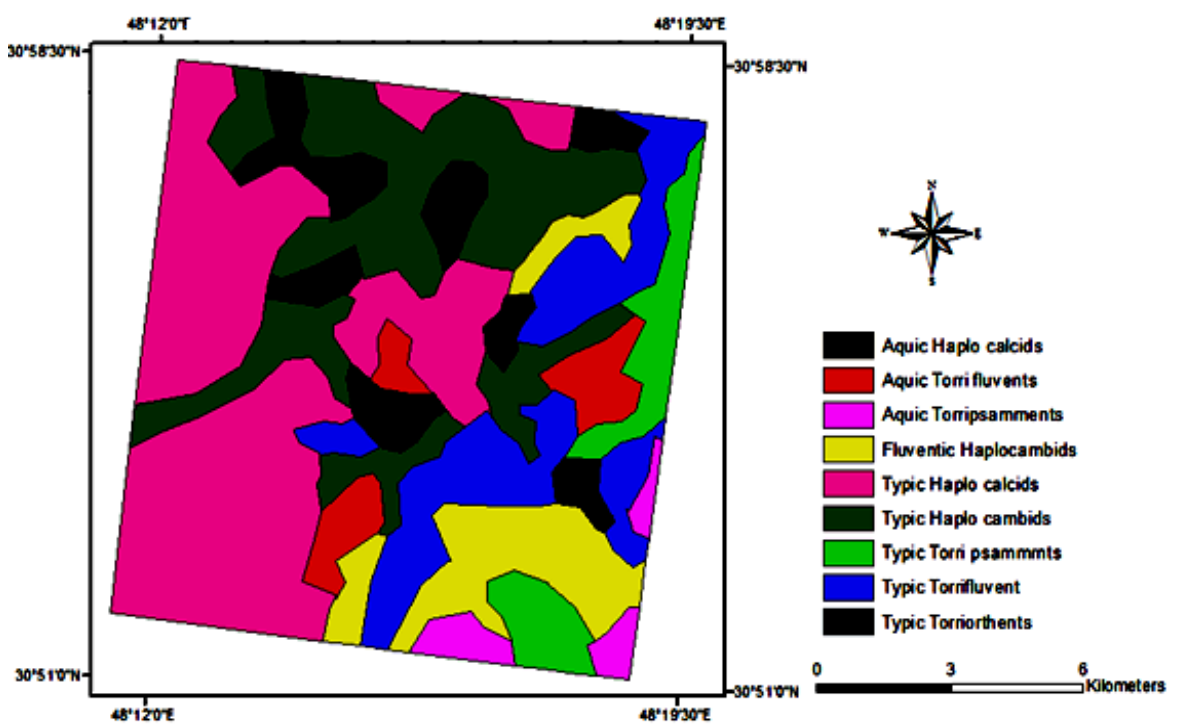

شكل r. گروههاى بزرى خاك منطقه مطالعاتى (USDA, Y०|f)

PQI $=\left(\mathrm{S}_{\mathrm{R}} \times \mathrm{S}_{\mathrm{T}} \times \mathrm{S}_{\mathrm{D}} \times \mathrm{S}_{\mathrm{F}} \times \mathrm{S}_{\mathrm{Y}} \times \mathrm{S}_{\mathrm{P}} \times \mathrm{S}_{\mathrm{G}} \times \mathrm{S}_{\mathrm{W}}\right)^{\frac{1}{\wedge}}$

كـه در رابطـه (Y)، (Y) ، عبارتند از: زهكشى، بافت، عمق خاك، شـيب خـاك، سـنخريزه سطحى، عمق لايه غيرقابل نفوذ، هدايت هيدروليكى و ظرفيـت تخهدارى آب در خاك.

نمرهدهى يار امترهاى مورد نظر بهصورت تجربى بـوده و بـر

اساس تجربيات ساير يزوهشخران انجام شد. در اين روش همه

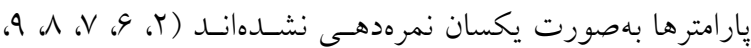

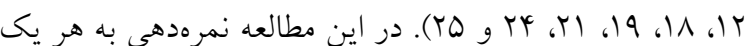
از يارامترها بر اساس شرايط خاص آنها صورت گرفت بـه ايسن

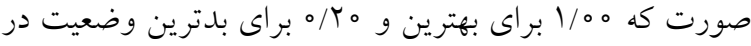
نظر كرفته شده است (V) (جدول l). نمرهدهى به هر يك از شاخص هاى تعريف شده بـر اسـاس اهميت آن شاخص در تناسب اراضى بـهـنظور توليسـ محصسول مورد نظر صورت مى گيرد. بر اين اساس ارزش صفر به منـاطق ردهبندى نشده اختصاص داده شده و مناطقى كه مناسب كشـت هستند به جِهار كلاس تقسيمبندى مىشوند كه عبارتند از: كاملاً مناسب (S)، داراى تناسب متوسط (SY)، داراى تناسب حسـداقل

$$
\text { (N) و نامناسب (S) }
$$

كيفيت فيزيكى خاك (Physical Quality Index)، سبس تناسب اراضى از رابطه (1) تعيين شد.

$\mathrm{LS}=(\mathrm{FQI} \times \mathrm{CQI} \times \mathrm{PQI})^{\frac{1}{r}}$

كسه در آن: LS فـاكتور تناسـب اراضسى، FQI شـاخص كيفيـت حاصلخيزى، CQI شـاخص كيفيـت شـيميايى و PQI شـاخص كيفيت فيزيكى خاى است.

شاخص كيفيت حاصلخيزى خاى بـا اسـتفاده از رابطـه (r) محاسبه مىشود:

$\mathrm{FQI}=\left(\mathrm{S}_{\mathrm{N}} \times \mathrm{S}_{\mathrm{P}} \times \mathrm{S}_{\mathrm{K}} \times \mathrm{S}_{\mathrm{Zn}} \times \mathrm{S}_{\mathrm{OM}}\right)^{\frac{1}{\omega}}$

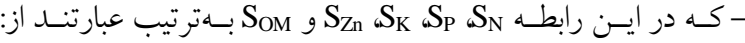
نيتروزن، فسفر، بِاسيم و روى قابل جذب و همجنين ماده آلى خاك. شاخص كيفيـت شـيميايى خــاك بـا اسـتفاده از رابطـه (r) محاسبه مىشود:

CQI $=\left(\mathrm{S}_{\mathrm{S}} \times \mathrm{S}_{\mathrm{E}} \times \mathrm{S}_{\mathrm{C}} \times \mathrm{S}_{\mathrm{H}}\right)^{\frac{1}{\kappa}}$

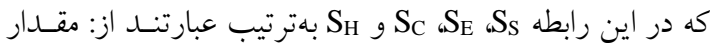
شورى خاى، درصد سديم تبادلى، مقدار آهك و و اكنش خاى.

شـاخص كيفيـت فيزيكسى خـاك بـا اسـتفاده از رابطـهـ (y)

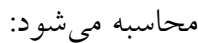


نشر يه علوم آب و خاك (علوم و فنون كشاورزى و منابع طبيعى) / سال بيست و سه / شماره دوم / تابستان \هـ1

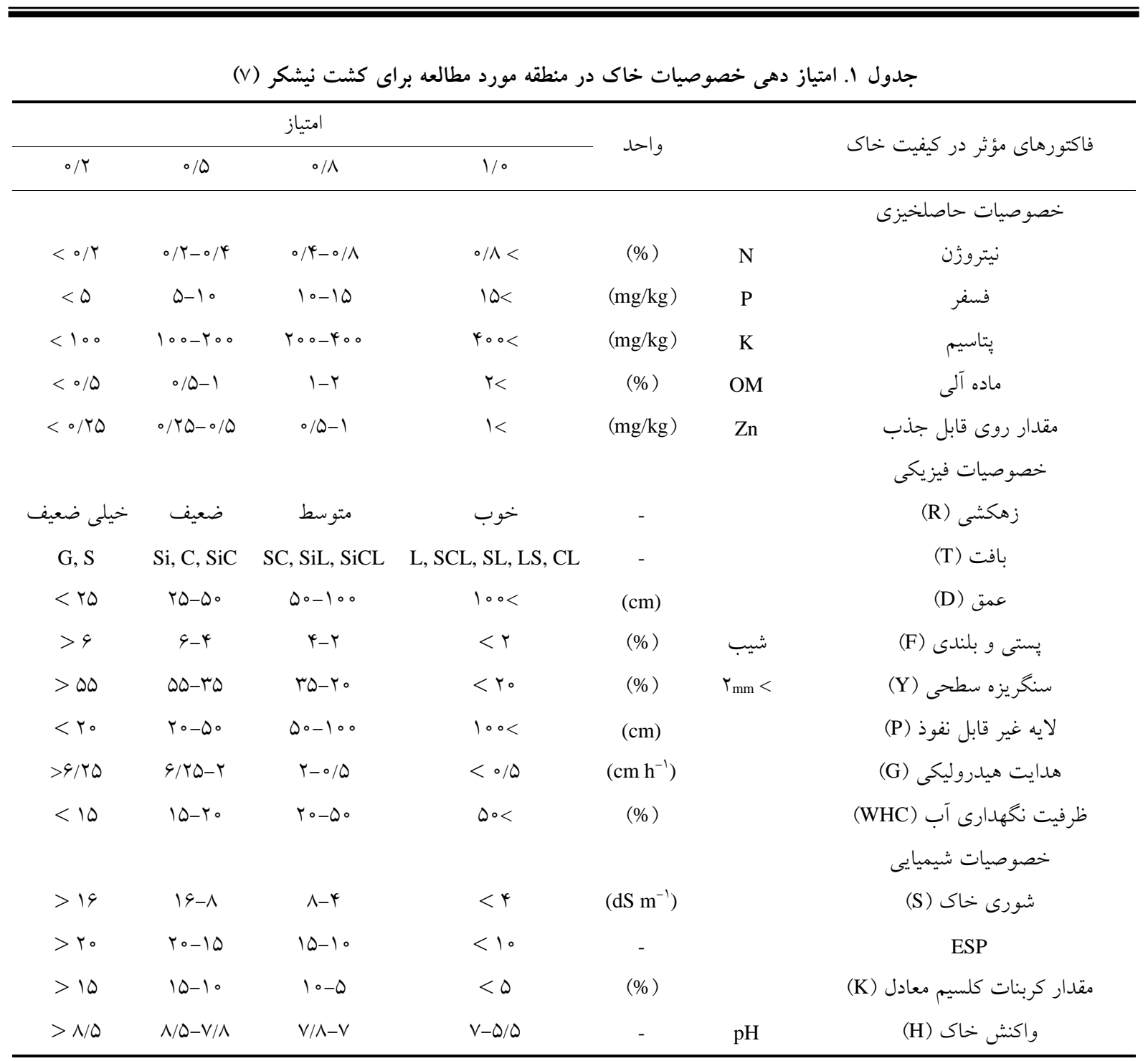

در انتها، نتايج بهدست آمده از مدل بيشنهاد شده در اين يزوهش براى هر يك از واحدها تعيين مىشود: $\mathrm{I}=\mathrm{A} \times \frac{\mathrm{B}}{100} \times \frac{\mathrm{C}}{100} \times \frac{\mathrm{D}}{100} \times \ldots$

كه در آن: I، شاخص تناسب و A نمره بافت خاى سطحى و B، C و D، مقادير نمرات ساير بارامترها هستند.

دامنه تغييرات نمرات بين صفر تا ه ما درصد بود كـه بـراى

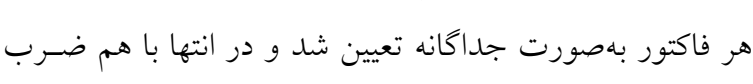
و شاخص اراضى را براى هـر يـكى از واحسدهاى نقشـه ايجــاد

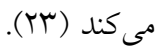

بهمنظور مقايسـه روش اسـتفاده شـده بـا روش اسـتورى و با روشهاى ريشه دوم و استورى كه بهطور معمول استفاده قرار مى گيرند، مورد مقايسه شدند. در روش ريشــه دوم از رابطـه (ه) بــراى محاسـبه تناسـب

$I=R_{\min } \times \sqrt{\frac{\mathrm{A}}{100} \times \frac{\mathrm{B}}{100} \times \frac{\mathrm{C}}{100} \times \ldots .}$

اراضى استفاده مىشود:

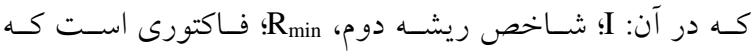
حداقل نمره را بهخود اختصاص داده، A A و C مقـادير نمـره دهى شده براى ساير فاكتورها است (ه (1). ريشـه دوم از ضـريب كايـا كـوهن (1990) اسـتفاده شـــ كـهـ

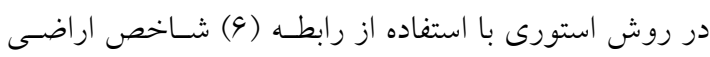


تعيين تناسب اراضى مزارع نيشكر مبتى بر شاخص كيفيت خاك با استفاده ...

جدول Y. شاخص حاصلخيزى خاك در منطقه مورد مطالعه (V)

\begin{tabular}{|c|c|c|c|c|}
\hline درصد & مساحت (هكتار) & 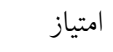 & 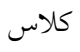 & شاخص حاصلخيزى خاى \\
\hline ro/०r & FYYq/9T & $0 / 9<$ & S) & كيفيت بالا \\
\hline$r q / \Lambda 4$ & VนNH/Q9 & $\circ / \mathrm{V}-0 / 9$ & Sr & كيفيت متوسط \\
\hline $\mid \psi / \wedge \Delta$ & $r 199 / 9 \mathrm{~V}$ & $\circ / 0-\circ / V$ & ST & كيفيت يايين \\
\hline$Q / T V$ & $\vee \wedge \circ / 1 \circ$ & $<\circ / 0$ & $\mathrm{~N}$ & 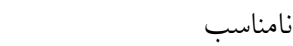 \\
\hline
\end{tabular}

جدول r. شاخص كيفيت شيميايى در منطقه مورد مطالعه (V)

\begin{tabular}{|c|c|c|c|c|}
\hline درصد & مساحت (هكتار) & 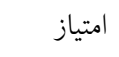 & كلاس & شاخص شيميايى خاى \\
\hline$T / V \circ$ & $400 / 09$ & $0 / 9<$ & SI & كيفيت بالا \\
\hline$\Delta Y / \circ \circ$ & D & $0 / \mathrm{V}-0 / 9$ & ST & كيفيت متوسط \\
\hline rN/ & DSYN/YQ & $\circ / 0-\circ / V$ & Sr & كيفيت يايين \\
\hline $\mathrm{V} / \mathrm{IV}$ & $1091 / 0 V$ & $<\circ / 0$ & $\mathrm{~N}$ & نامناسب \\
\hline
\end{tabular}

جدول +. شاخص كيفيت فيزيكى در منطقه مورد مطالعه (V)

\begin{tabular}{|c|c|c|c|c|}
\hline درصد & مساحت (هكتار) & 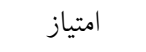 & كلاس & شاخص فيزيكى خاك \\
\hline $11 / 99$ & $|T| \circ \mid / 09$ & $\circ / V Q<$ & $\mathrm{S}_{1}$ & كيفيت بالا \\
\hline $1 \pi / 00$ & $1941 / 91$ & $\circ / 0 \circ-\circ / V Q$ & $\mathrm{~S}_{r}$ & كيفيت متوسط \\
\hline$r / 1 r$ & $r 10 / 99$ & $\circ / Y \Delta-\circ / \Delta \circ$ & $\mathrm{S}_{r}$ & كيفيت پيايين \\
\hline r/lr & $4 \notin 4 / 11$ & $<0 / T \Delta$ & $\mathrm{N}$ & نامناسب \\
\hline
\end{tabular}

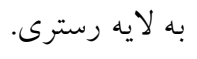$$
\text { بهصورت رابطه (V) (V) است: }
$$

r- ردهبندى لايههاى رسترى برمبناى اطلاعات جداول (r، س و

$$
\text { (1) (شاخص هاى كيفيت خاى سه گانه) }
$$

$$
K=\frac{P(A)+P(E)}{1-P(E)}
$$

r- وزن دهى و منطبق كردن لايههاى ايجاد شده بر يكديخر. ץ- ردهبندى مجدد تمام بيكسل ها در لايه رسترى سـاخته شـده

بهمنظور تعيين كلاس هاى تناسب اراضى بر مبناى جدول (ه). ه- تهيه نقشه تناسب اراضى منطقه مورد مطالعه.

\section{نتايج و بحث}

بر اساس تصوير ماهواره لندسـت هشـت در تـاريخ و ج جـولاى

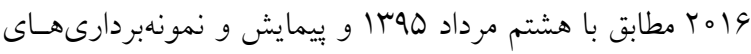
صحرايى، فيزيو گرافى منطقه مـورد مطالعـه تعيـين شـــ. بـهعلت
در اين رابطه K ضريب كايا است و P(A) قرارداد نسـبى مشـاهده شده بين ارزيابها و P(E) احتمال فرضى قرارداد شانس است. مقدار ضريب كايا بين صفر تا هـ/1 است. اخر هيج كونه توافقى بين موارد ارزيابى وجود نداشته باشـد، ضـريب كايـا صـفر و اخـر توافق كامل وجود داشته باشد، ضريب كايا برابر با هـ/1 مىشود.

$$
\text { تعيين كلاسهاى تناسب اراضى }
$$
بهمنظور تعيين كلاسهاى تناسب اراضى مراحل زير انجام شدند: 1- تبديل شاخصىهاى فيزيكى، شيميايى و حاصسلخيزى خـاى سرى 
نشر يه علوم آب و خاك (علوم و فنون كشاورزى و منابع طبيعى) / سال بيست و سه / شماره دوم / تابستان لهه|

جدول ه. تناسب اراضى منطقه مورد مطالعه (V)

\begin{tabular}{|c|c|c|c|c|}
\hline درصد & مساحت (هكتار) & امتياز & كلاس & تناسب اراضى \\
\hline$T V / \Psi_{0}$ & $9 \mu \circ V / 90$ & $\circ / 1 \circ-1 / 0 \circ$ & $\mathrm{S}_{1}$ & تناسب بالا \\
\hline GY/Ar & $1 \circ 0 r / \circ q$ & $0 / 90-0 / 10$ & $\mathrm{~S}_{Y}$ & تناسب متوسط \\
\hline $\mathrm{V} / \mathrm{II}$ & $r q 4 / r q$ & $0 / 40-0 / 90$ & $\mathrm{~S}_{\mathrm{r}}$ & تناسب حدو اسط \\
\hline$r / 94$ & $r \circ \Delta / / Y q$ & $<_{0} / \varphi_{0}$ & $\mathrm{~N}$ & نامناسب \\
\hline
\end{tabular}

جدول 9. ردهبندى اراضى منطقه مورد مطالعه تا سطح تحت گروه و درصد مساحت هر يك از ردهها

\begin{tabular}{|c|c|c|c|}
\hline درصد & مساحت (هكتار) & رده & رديف \\
\hline$r / 4 i$ & 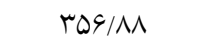 & Aquic Torripsamments & 1 \\
\hline $14 / 44$ & $19 V / / 91$ & Typic Torrifluvents & r \\
\hline $4 / 91$ & GNY/AT & Aquic Torrifluvents & r \\
\hline $9 / 9 \circ$ & $901 / 49$ & Typic Torri psammrnts & r \\
\hline$T M / \Delta \Lambda$ & r199/19 & Typic Haplocambids & 0 \\
\hline 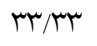 & rqR/Tr & Typic Haplocalcids & 4 \\
\hline$r / Q V$ & QYN/TI & Aquic Haplocalcids & v \\
\hline $9 / 41$ & |rqm/rq & Fluventic Haplocambids & $\wedge$ \\
\hline $0 / 94$ & $\Lambda \mu_{\Lambda} / \mu_{1}$ & Typic Torriorthents & 9 \\
\hline
\end{tabular}

برخى افقهاى تحت الارض ديده مىشـود، امـا در هــيجكـدام از

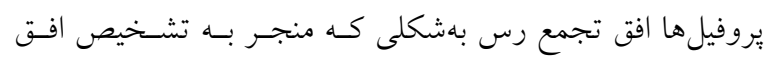

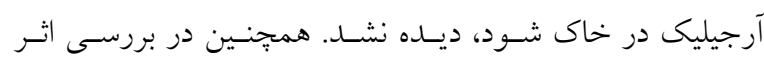

شرايط آبرفتسى روى بيـدايش و خصوصسيات خـاك ايسن نتيجسه

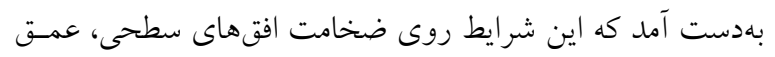

سولوم، بافت، مقدار سنكريزه موجود در سـطح و نسيمرخ خـاك، درصد رطوبت اشباع، ظرفيت تبادل كاتيونى، مقدار و شكل آهك ثانويه تجمع يافته در افتهاى مختلف يروفيلها بيشـترين تـأثير را

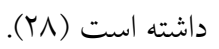

$$
\text { تناسب اراضى }
$$

در مدل يِينهاد شده بهمنظور بررسى تناسب اراضى منطقه مورد مطالعه از سه شاخص كيفيت حاصسلخيزى، كيفيـت شـيميايى و كيفيت فيزيكى خاك استفاده شد. مقادير هر شاخص محاسبه و
طغيانهاى فصلى، رسـوبات رودخانـه كـارون در سـطح اراضسى نهشته شده و منجر به هموار شدن سطح اراضى منطقه شده است. بر اين اساس فيزيو گرافى منطقه مورد مطالعسه دشـتهاى آبرفتسى است. در بيشتر يروفيلهاى حفر شده آثار تكاملى بهنـدرت قابـل تشخيص بود و در مواردى تغييرات شديد بـافتى بـين افقهـا بـهـ وضوح قابل تشخيص است (YN). مطابق سيستم جـامع ردهبنـدى

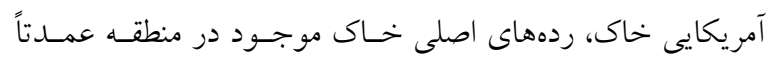
انتىسول و در برخى نقاط اريدىسول (جــول 9) تعيسين شـدند (Y)). خاكها بدون تكامل تيروفيلسى و يـا داراى تكامـل ضـعيفى هستند كه بهتدريج با كاهش شيب و كاهش سنخريزه در سـطح و نيمرخ خاك، بـه خاكهـاى داراى افـق مشخصسه زيرسـطحى از جمله افق كمبيك با مختصر تكامل بروفيلى تبـديل مىشـوند. در قسمتهايى كه داراى شيب بسيار كمى هستند مىتوان افق تجمع

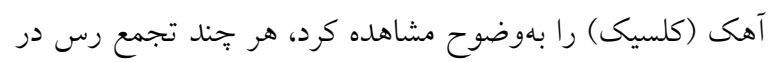




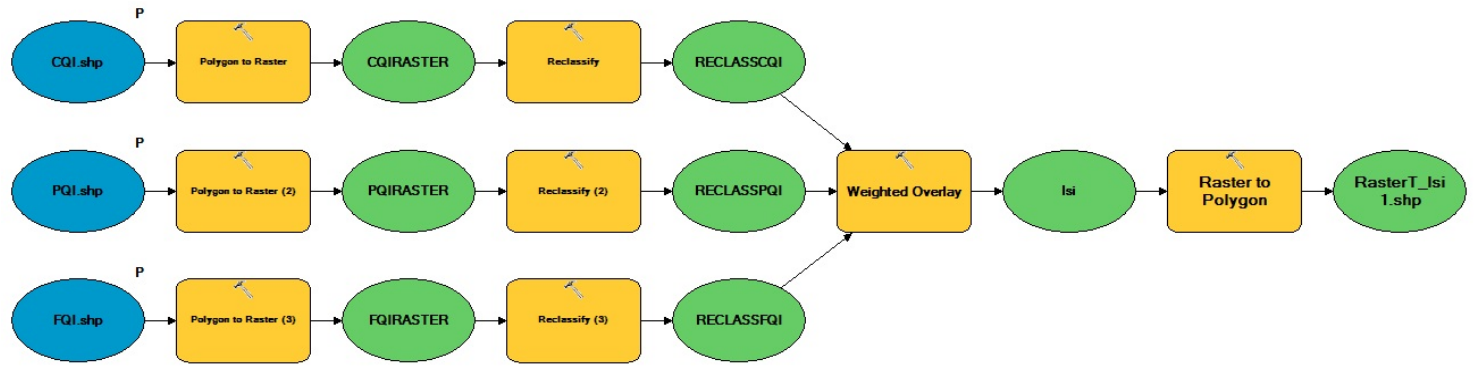

شكل ثا. فلوجارت مدلسازى تناسب اراضى در محيط ArcGIS

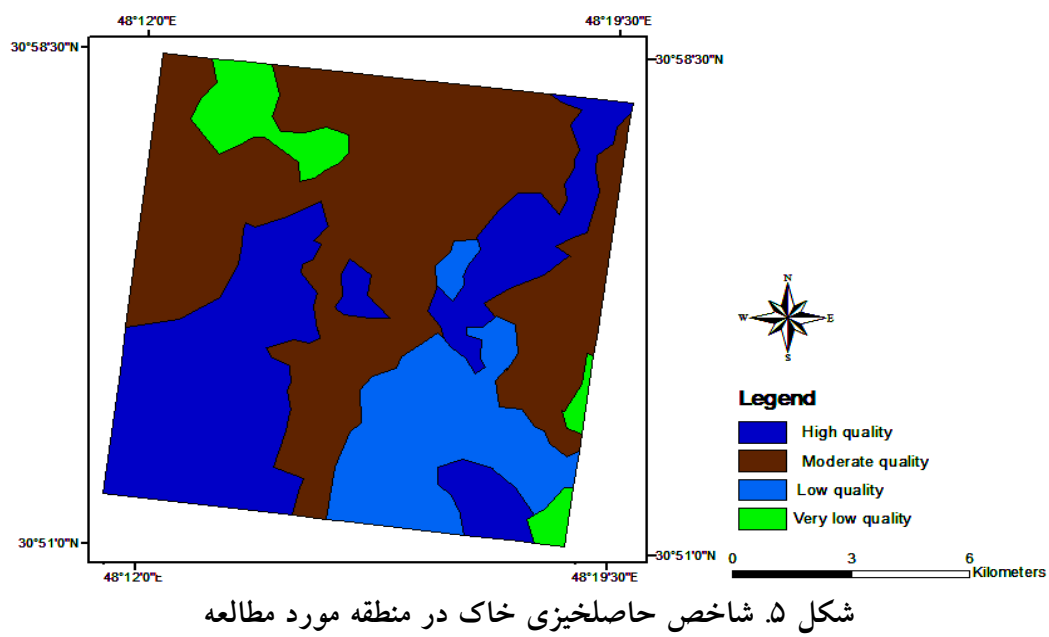

با توجه به فاكتورهاى مورد نظر براى حاصسلخيزى مى تـوان نتيجه كرفت علت قـرار كـرفتن اراضسى در كلاسهـاى يـايين كمبود نيتروزن، فسفر، يتاسيم، روى قابل جذب و همجنين ماده آلى در خاك هستند (جدول r و شكل ه).

\section{شاخص كيفيت شيميايى خاك}

خصوصيات شيميايى خاك، رشــ گياهـان و كيفيـت و كميـت محصولات توليد شده را تحــت تـأثير قـرار مىدهـد (V و YY). اطلاعات مربوط به شاخص كيفيت شيميايى منطقه مورد مطالعه در جدول (r) و شكل (ه) ارائه شده است. نتايج جــدول نشـان مىدهد كه T/V درصد از اراضى در كلاس كيفيت بالا (ST)، Or

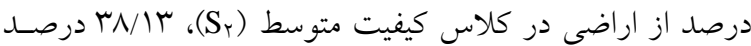
از اراضى در كلاس كيفيت بايين (S/IV و V/ درصد از اراضسى در كلاس نامناسب (N) از لحاظ كيفيـت شـيميايى خـاك قـرار
سيس با استفاده از روشهـاى درونيـابى و طبقهبنـدى مجــدد، نقشه يهنهبندى مربوط به هر شاخص تهيه و در انتها با اسـتفاده از روش وزندهـى و منطبـق كـردن لايسههاى توليـــ شــده بــر

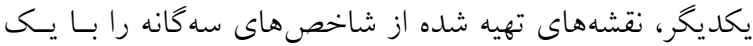
ديخر ادغام كرده و نقشه ارزيـابى اراضسى نهـايى منطقسه مـورد مطالعه تهيه شد.

\section{شاخص كيفيت حاصلخيزى خاى}

اطلاعات مربوط به ايسن شـاخص در جـدول (Y) و شكل (Y)

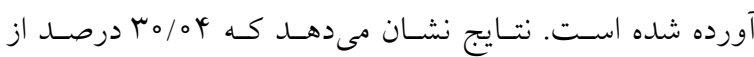

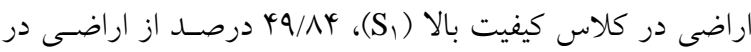

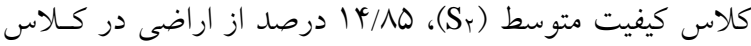

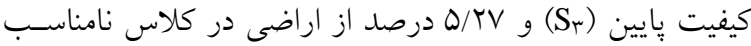
(N) 
نشر يه علوم آب و خاك (علوم و فنون كشاورزى و منابع طبيعى) / سال بيست و سه / شماره دوم / تابستان لهه|
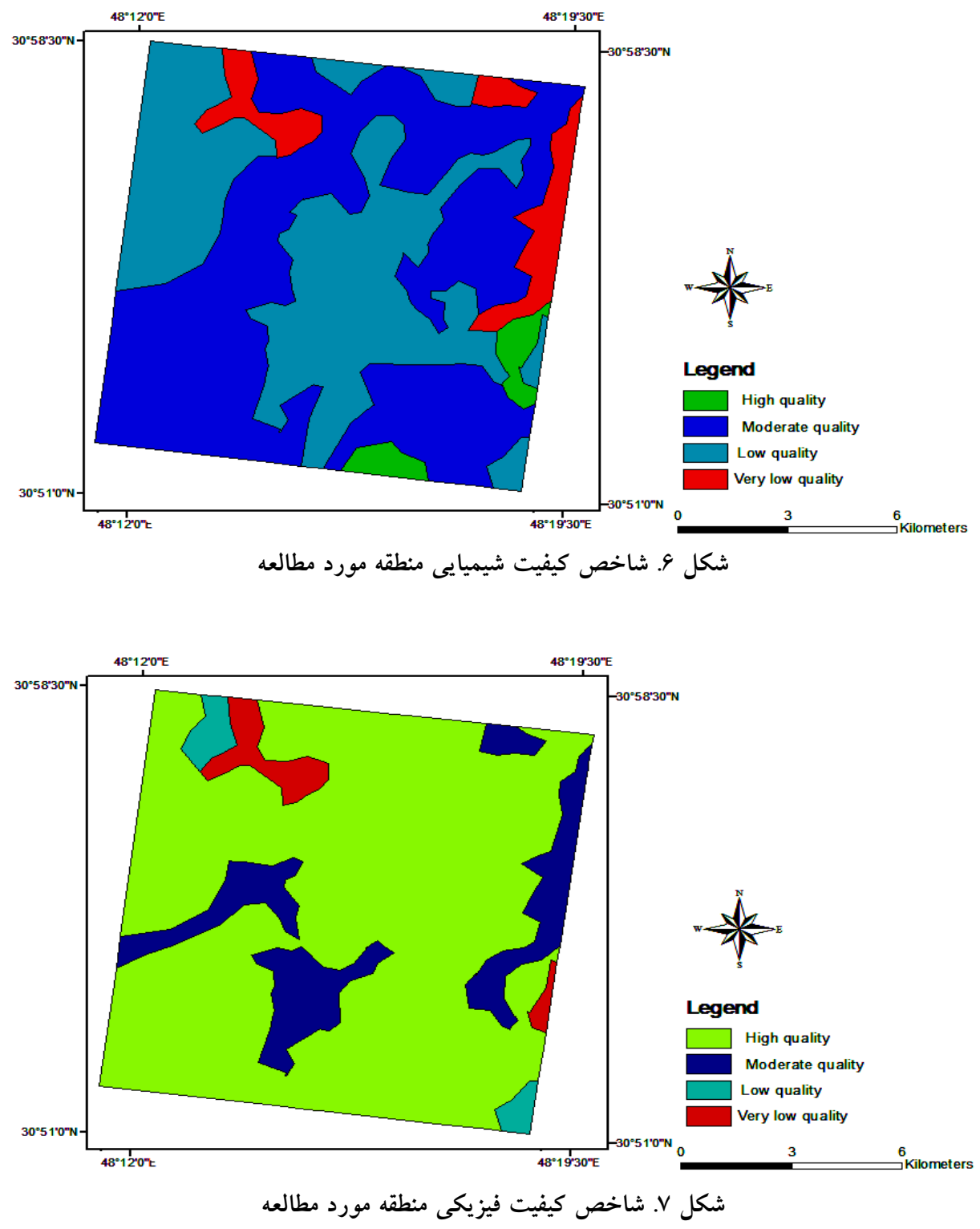

نتايج بهدست آمده از شاخص كيفيـت فيزيكسى خـاك نشـان

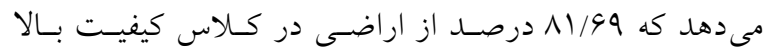

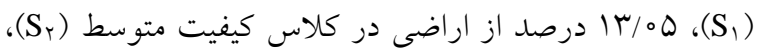

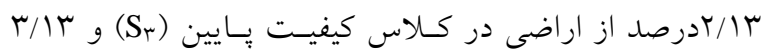

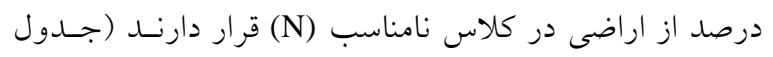

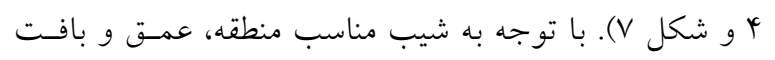

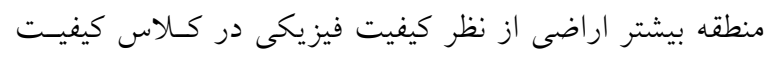

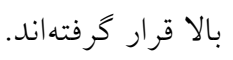

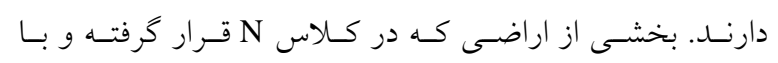

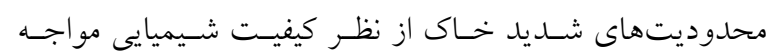
هستند (جدول باو شكل 9). شاخص كيفيت فيزيكى خاك رشد تمام محصولات كشاورزى بـهـور مستقيم بـهـ شـرايط

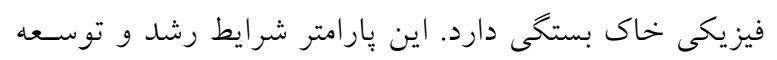

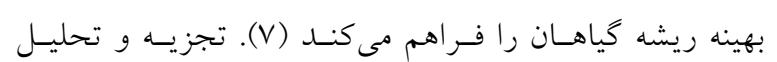



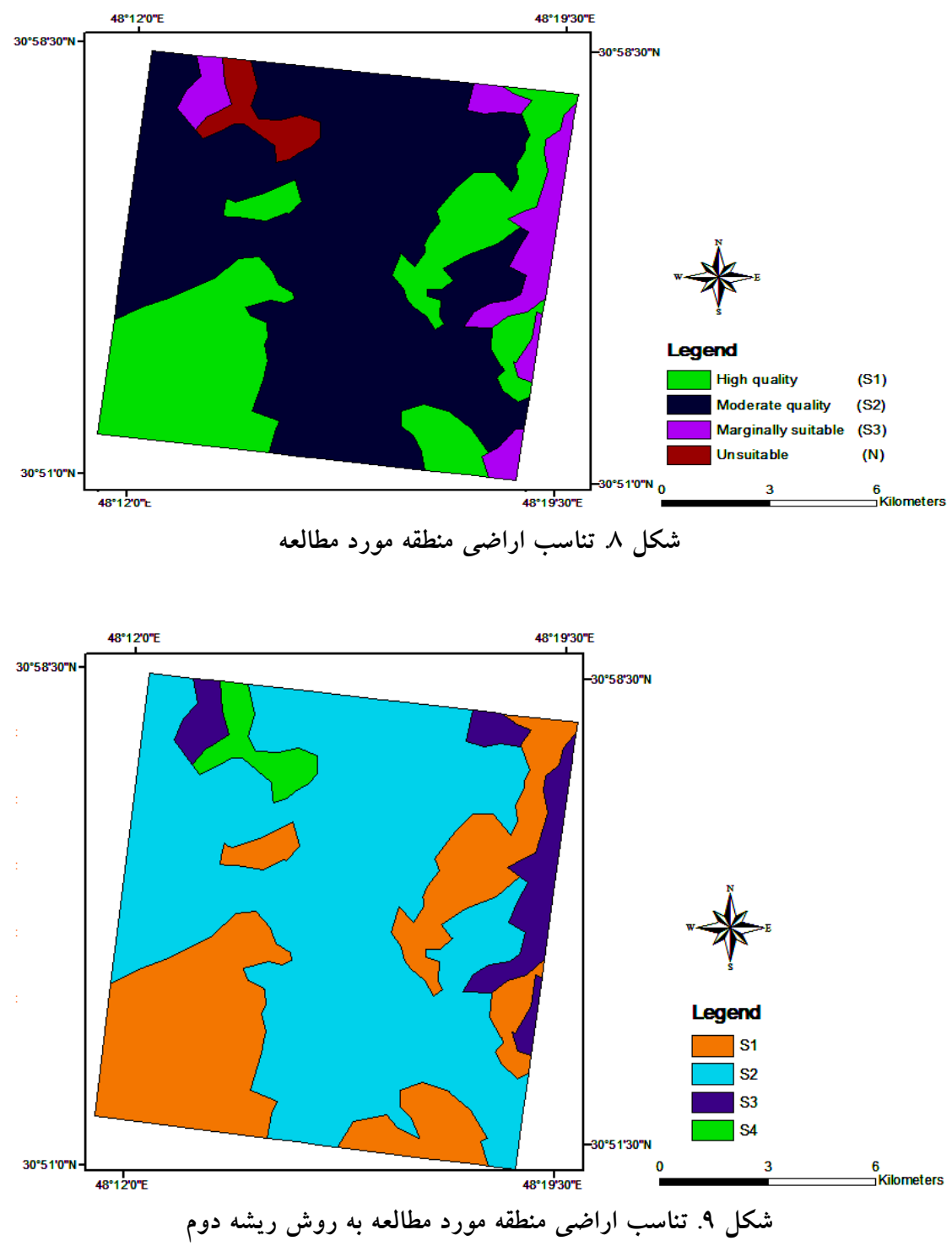

و شيميايى اين مناطق نيز بسيار نامناسب بوده اسـت (جــدول ه و ارزيابى تناسب اراضى

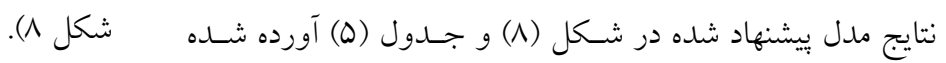
نتايج روش ارزيابى ريشه دوم نشان داد كه YN/DS درصد از است. اين نتايج نشان مىدهد كه بيشستر اراضسى در كـلاس داراى

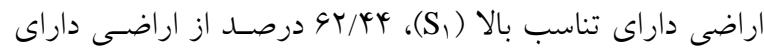
تناسب بالا (High Suitable) (S) و اراضى داراى تناسب متوسط

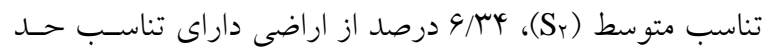

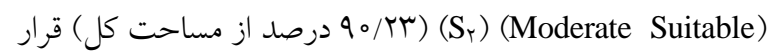

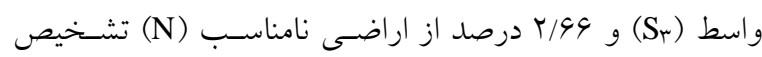

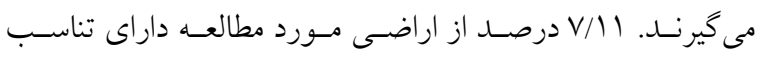
داده شدند (جدول V و شكل 9).

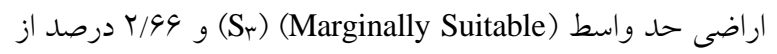
نتايج روش استورى نشان مىدهد كه 9/11 درصد از اراضى در كلاس بسيار مناسـب (S) VI/09 درصسد از اراضسى داراى اراضى نامناسب (N) (Unsuitable) براى گيـاه نيشـكر تشـخيص داده شدند. نقشه تهيه شده نشان مىدهد كه خصوصيات فيزيكى 
نشر يه علوم آب و خاك (علوم و فنون كشاورزى و منابع طبيعى) / سال بيست و سه / شماره دوم / تابستان لهه|

جدول V. تناسب اراضى به روش ريشه دوم در منطقه مورد مطالعه (YY و (YV)

\begin{tabular}{|c|c|c|c|c|}
\hline درصد & مساحت (هكتار) & 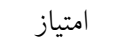 & 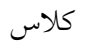 & تناسب اراضى به روش ريشه دوم \\
\hline TN/DG & $r Y \circ / \wedge r$ & $V \Delta-100$ & $\mathrm{~S}_{1}$ & تناسب بالا \\
\hline$G Y / 4 Y$ & $9 r+9 / 09$ & $\Delta \circ-V Q$ & $\mathrm{~S}_{r}$ & تناسب متوسط \\
\hline $9 / \mu y$ & $Q M \wedge / \Delta V$ & $r \Delta-Q_{0}$ & $\mathrm{~S}_{r}$ & تناسب حدواسط \\
\hline r/99 & $r q 4 / r q$ & $<r \Delta$ & $\mathrm{N}$ & 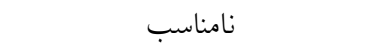 \\
\hline
\end{tabular}

جدول ^ تناسب اراضى به روش استورى در منطقه مورد مطالعه (YO)

\begin{tabular}{|c|c|c|c|c|}
\hline درصد & مساحت (هكتار) & 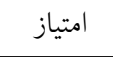 & 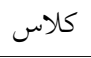 & تناسب اراضى به روش استورى \\
\hline $9 / 11$ & IYOH/TG & $V \Delta-1 \circ \circ$ & $\mathrm{S}_{1}$ & تناسب بالا \\
\hline $21 / \circ 9$ & $1 \circ \Delta r \circ / 10$ & $\Delta \circ-V \Delta$ & $\mathrm{S}_{r}$ & تناسب متوسط \\
\hline $9 / 49$ & $|F \cdot 1 /| V$ & $r \Delta-Q_{0}$ & $\mathrm{~S}_{r}$ & تناسب حدواسط \\
\hline $9 / 94$ & IFTN/GQ & $<r \Delta$ & $\mathrm{N}$ & نامناسب \\
\hline
\end{tabular}

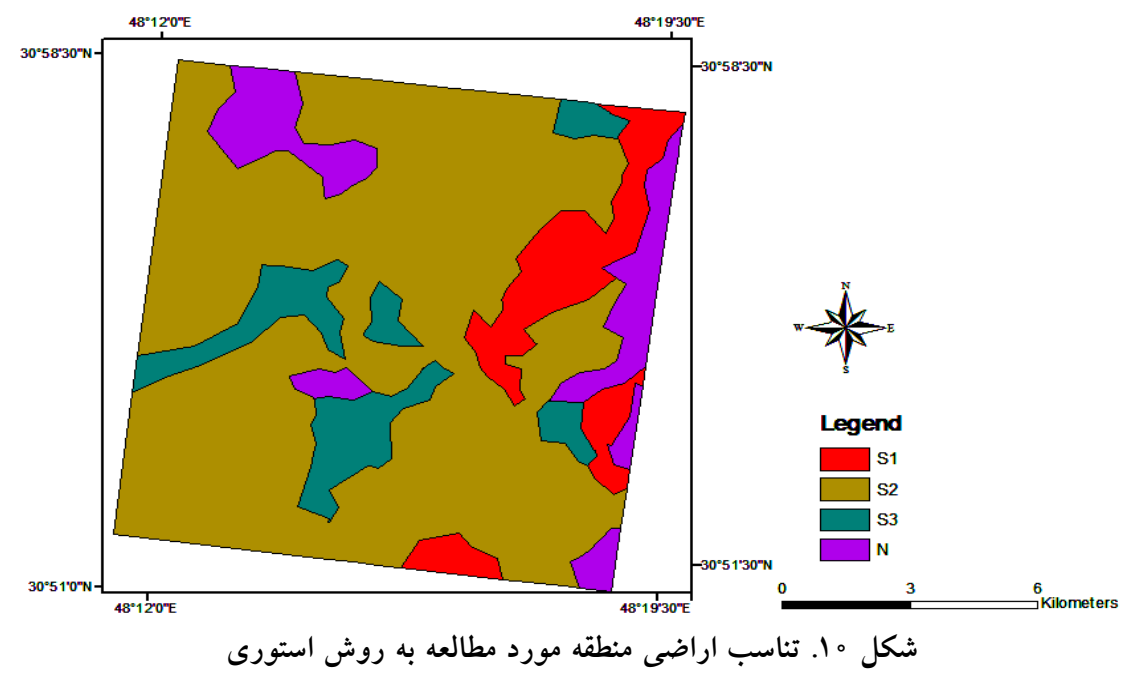

قرار گرفتهاند (جدول ^). اين نتايج با نتايجى كه از روش ريشه دوم بهدست آمده مطابقت قابل توجهى را نشان مىدهد (جدول

بهمنظور بررسى و مقايسه بيشتر نتايج بهدست آمده از مـدل بيشنهاد شده و روشهاى ريشه دوم و استورى از ضـريب كايـا

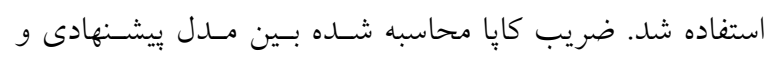
روش ريشه دوم NT/ه است. اين مقدار نشاندهنده سطح بالايى از هماهنكى بين مدل بيشنهاد شـده و روش ريشـه دوم اسـت.
تناسب متوسط (SY)، 94/9 درصد از اراضسى داراى تناسـب

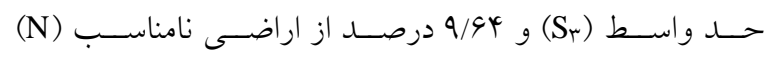
تشخيص داده شدند (جدول م و شكل م1) . در مقايسه با روشهاى ريشه دوم و استورى، نتايج مدل بيشنهاد شده در اين تحقيق نشان مىدهد كه rV/T درصسد از اراضسى در

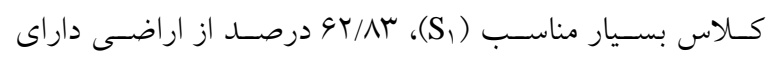
تناسب متوسط (SY)، V/II درصد از اراضى داراى تناسـب حسد واسط (Sr) و r/94 درصد از اراضسى در كـلاس نامناسـب (N) 


\begin{tabular}{|c|c|c|c|c|c|}
\hline \multicolumn{6}{|c|}{ جدول 9. مقايسه روشهاى استورى و ريشه دوم با روش مورد استفاده } \\
\hline & روش ريشه دوم & & \multicolumn{3}{|c|}{ روش استورى } \\
\hline & صحت كلى 0\% 9 درصد & & \multicolumn{3}{|c|}{ صحت كلى Q9/TV درصد } \\
\hline & ضريب كايا م 1 م درصد & & \multicolumn{3}{|c|}{ ضريب كايا مN/Noم درصد } \\
\hline & درستى طبقات كلاسبندى & & \multicolumn{3}{|c|}{ درستى طبقات كلاسبندى } \\
\hline 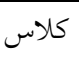 & روش مورد استفاده & 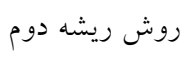 & 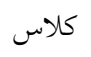 & روش مورد استفاده & 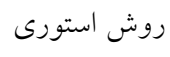 \\
\hline $\mathrm{S}_{1}$ & VI/AT & $10 \%$ & $\mathrm{~S}_{1}$ & $V Q / \circ \circ$ & $00 / 00$ \\
\hline $\mathrm{S}_{r}$ & $90 / 00$ & $9 \circ / 49$ & $\mathrm{~S}_{\mathrm{r}}$ & $\Lambda T / \mu$ & $V \circ / \circ \circ$ \\
\hline $\mathrm{S}_{r}$ & $100 \%$ & $\Lambda \circ / \circ \circ$ & $\mathrm{S}_{r}$ & ro/ $/ 0$ & $r_{\circ} / 0 \circ$ \\
\hline $\mathrm{N}$ & $10 \%$ & $100 \%$ & $\mathrm{~N}$ & $19 / 94$ & $100 \%$ \\
\hline
\end{tabular}

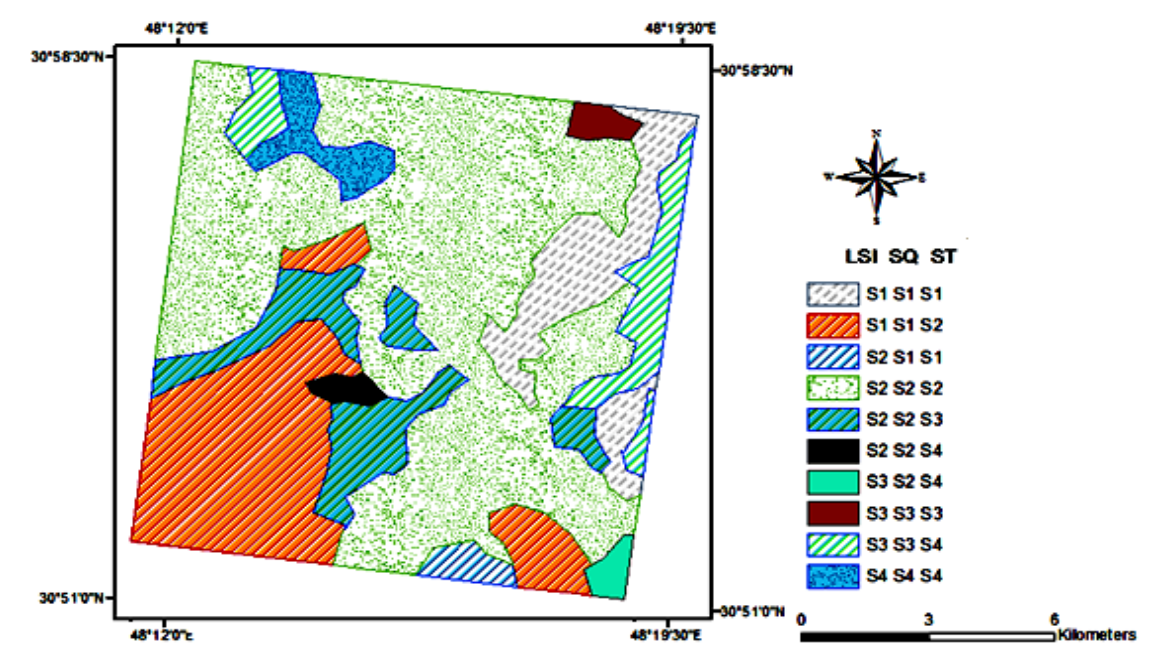

شكل ll. تلفيق سه روش بر آورد تناسب اراضى (روش مورد مطالعه، روش ريشه دوم و روش استورى) كلاسهاى ارزيابى تناسب اراضى بهترتيب از راست به جِّ: روش استورى، روش ريشه دوم و روش مورد مطالعه

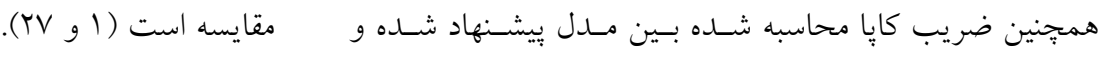

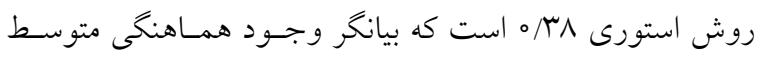

$$
\begin{aligned}
& \text { نتيجه كيرى } \\
& \text { بين اين دو روش است (جدول 9) }
\end{aligned}
$$

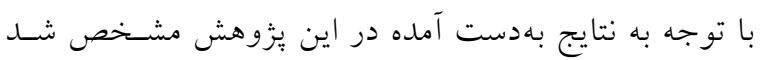

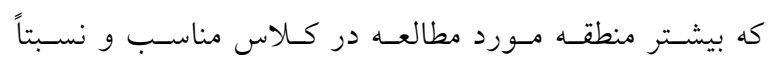
مناسب براى كشت نيشكر قرار كرفته اسـت. نتسايج بهدسـت

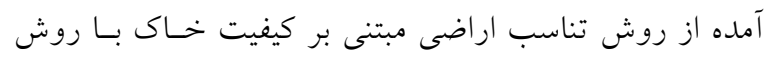

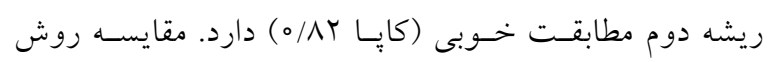
تناسب اراضى مبتنى بر كيفيت خاى با روش اسـتورى نشـان
شكل (11) نقشه تلفيقى از سه روش مورد استفاده است. در

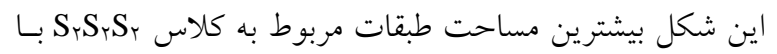

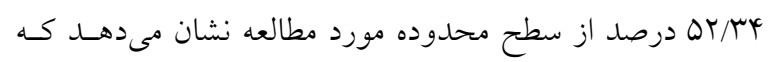
بيشتر مساحت اين منطقه در سه روش مورد بررسى، در كـلاس

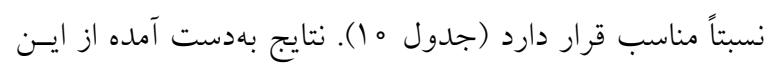

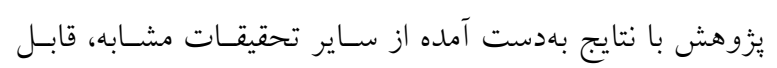


نشر يه علوم آب و خاك (علوم و فنون كشاورزى و منابع طبيعى) / سال بيست و سه / شماره دوم / تابستان \هب|

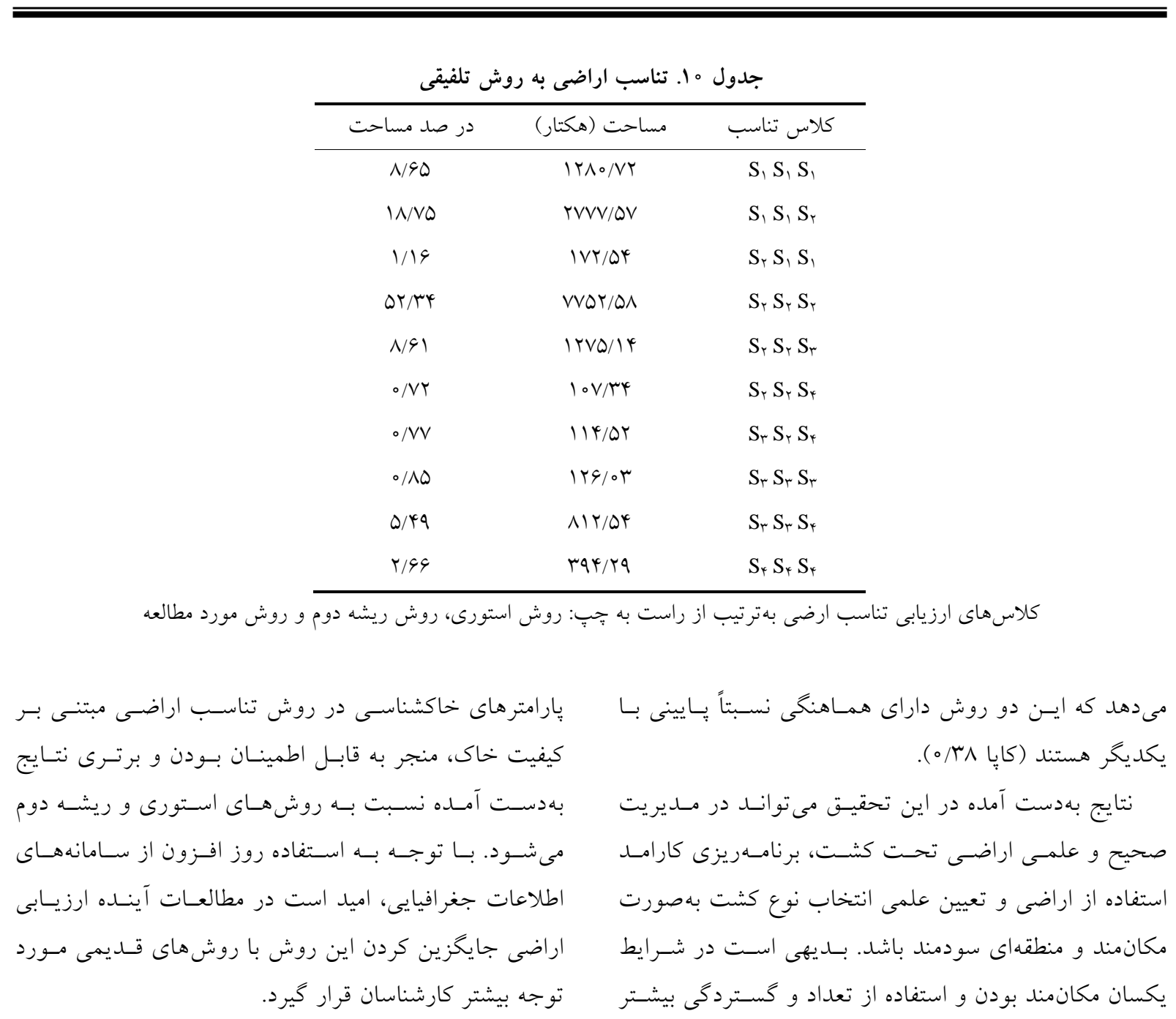

\section{منابع مورد استفاده}

1. Ashraf, S. and B. Normohammadan. 2011. Qualitative evaluation of land suitability for wheat in northeast Iran using FAO methods. Indian Jornal of Science of Technology 4: 703-707.

2. Ashraf, S., R. Munokyan, B. Normohammadan and A. Babaei. 2010. Qualitative land suitability evaluation for growth of wheat in northeast of Iran. Reserch Journal of Biology Science 5: 548-552.

3. Akıncı, H., A. Yavuz Ozalp and B. Turgut. 2013. Agricultural land use suitability analysis using GIS and AHP technique. Computers and Electronics in Agriculture 97: 71-82.

4. Bowman, R. A. 1988. A rapid method to determine total phosphorus in soils. Soil Science Society American Journal 52: 1301-1304.

5. Chen, J. 2014. GIS-based multi-criteria analysis for land use suitability assessment in City of Regina. Environmental Systems Reserch 3: 1-10.

6. El Baroudy, A. A. 2016. Mapping and evaluating land suitability using a GIS- based model. Catena 140: 96-104.

7. FAO. 1976. A Framework for Land Evaluation. Food and Agriculture Organization of the United Nations. Soils Bulletin. No. 32. FAO, Rome.

8. FAO. 1985. Guidelines: Land Evaluation for Irrigated Agriculture. Soil Bulletin. No. 55. FAO. Rome.

9. FAO. 1991. Guidelines for Land Evaluation for Extensive Grazing. Food and Agriculture Organization of the United Nations. Soils Bulletin. No. 58. FAO, Rome.

10. FAO. 2006. Guidelines for Soil Description. Fourth ed. FAO. Rome (ISBN 92-5-105521-1).

11. Halder, J. C. 2013. Land suitability assessment for crop cultivation by using remote sensing and GIS. Journal of 
Geography and Geology 5: 65-74.

12. Jackson, M. L. 1967. Soil Chemical Analysis. Prentice Hall Inc. Engle-wood Cliffs, N. S. Constable \& Co. Ltd., London.

13. Jackson, M. L. 1973. Soil Chemical Analysis. Constable and Co. Ltd. Prentice Hall of India Pvt. Ltd., New Delhi.

14. Khiddir, S. M. 1986. A Statistical Approach in the Use of Parametric Systems Applied to FAO Framework for Land Evaluation. State University of Ghent. Belgium.

15. Klute, A. 1995. Hydraulic conductivity and diffusivity. PP. 115-184. In: Physical and Mineralogical Methods. Second ed. American Society of Agronomy. Madison. WI.

16. Lindsay, W. L. and W. A. Norvell. 1978. Development of DTPA soil test for zink, iron, manganese and copper. Soil Science Society American Journal 43: 966-972.

17. Maleki, P., A. Landi, G. H. Sayyad, J. Baninemeh and G. H. Zareian. 2010. Application of fuzzy logic to land suitability for irrigated wheat. In: Proceeding of the $19^{\text {th }}$ World Congress of Soil Science, Soil Solutions for a Changing World. Brisbane. Australia.

18. Mustafa, A. A., M. Singh, R. N. Sahoo, N. Ahmed, M. Khanna, A. Sarangi and A. K. Mishra. 2011. Land suitability analysis for different crops: a multi criteria decision making approach using remote sensing and GIS. Researcher 3: 61-84.

19. Page, A. L., R. H. Miller and D. R. Keeney. 1982. Methods of Soil Analysis. 2 Ed. American Society of Agronomy, Madison, Wisconsin, U.S.A.

20. Rezaei, S. A., R. J. Gilkes, S. S. Andrews and H. Arzani. 2006. Soil quality assessment in semiarid rangeland in Iran. Soil Use Management 21: 402-409.

21. Rono, F. and C. Mundia. 2016. GIS based suitability analysis for coffee farming in Kenya. Internatinal Journal of Geomatics and Geosciences 6: 3-16.

22. Storie, R. 1978. Storie Index Rating. University of California Division of Agricultural Sciences Special Publication 3203, Oakland.

23. Sys, C., E. Van Ranst and J. Debaveye. 1991. Land Evaluation. Part III. General Administration for Development Cooperation, Brussels.

24. Sys, C., E. Van Ranst, J. Debaveye and F. Beernaert. 1993. Land Evaluation. Part III. Crop Requirements. Agr Publication No. 7. ITC Ghent.

25. USDA. 2014. Keys to Soil Taxonomy. Eleventh ed. United States Department of Agriculture. Natural Resources Conservation Service (NRCS). United States.

26. Vargahan, B., F. Shahbazi, M. Hajrasouli. 2011. Quantitative and qualitative land suitability evaluation for maize cultivation in Ghobadlou Region. Iranian Journal of Applled Science 4: 91-104.

27. Zabihi, H., A. Ahmad, I. Vogeler, M. Nor Said, M. Golmohammadi, B. Golein and M. Nilashi. 2015. Land suitability procedure for sustainable citrus planning using the application of the analytical network process approach and GIS. Computers and Electronics in Agriculture 117: 114-126.

28. Zahirnia, A. and M. Alimohamadi. 2007. Investigation of morphological, physicochemical, mineralogical and classification of cultivated sugarcane lands in southern Khuzestan. In: Proceeding of the $10^{\text {th }}$ Iranian Soil Science Congress, Karaj, Iran.

29. Zahirnia, A. and H. Matinfar. 2016. Estimation of yield of irrigated wheat fields based on data from Landsat 8 satellite in southwestern region of Khuzestan province. In: Proceeding of the First National Conference on Remote Sensing and Geographic Information Systems in Earth Sciences. Shiraz, Iran. 


\title{
Determination of the Land Suitability of Sugarcane Fields Based on Soil Quality Index Using a Geographic Information System
}

\author{
A. R. Zahirnia* and H. R. Matinfar ${ }^{1}$
}

(Received: August 10-2017 ; Accepted: June 25-2018)

\begin{abstract}
Determination of land suitability is one of the land evaluation methods that can determine the best use of land in each area. The purpose of this research was to determine the land suitability of Mirza Kuchak Khan's cultivation and industry fields based on the soil quality indicators and a geographic information system (GIS), and compare the results with those obtained by methods of land evaluation and root strategies. For this purpose, information on soil profiles and the amount of organic matter, phosphorus, nitrogen, potassium, zinc, drainage, texture, depth, topography, surface rocks and gravel, impervious layer depth, hydraulic conductivity, water holding capacity, electrical conductivity, reaction $\mathrm{PH}$ ), calcium carbonate, and exchangeable sodium percent of the study area were collected. Land suitability classes based on the quality indices of fertility, chemical quality, and physical quality of soil were defined. The results showed that $27.4 \%$ of the land belonged to the very good class (S1), $62.83 \%$ of the land could be assigned to the suitable class (S2), $11.7 \%$ of the land was put in the low proportion class (S3), and $2.66 \%$ the land was in the inappropriate class (N). Also, based on the comparison of the results of the method based on the soil quality with the square root method, Kappa coefficient was 0.82 , while it was equal to 0.38 for the Storie method.
\end{abstract}

Keywords: Land Evaluation, Khuzestan South West Region, Digital Maps, Storie Method, Square Root Method

1. Department of Soil Science, Faculty of Agriculture, Lorestan University, Lorestan, Iran.

*: Corresponding Author, Email: arzahirnia@gmail.com 